\title{
Unia polsko-rosyjska z 1815 r. na tle unii lubelskiej \\ i projektów unii Rzeczypospolitej i Rosji z XVI i XVII w.
}

\section{Wprowadzenie}

Królestwo Polskie, zwane również Kongresowym, nie ma w polskiej historiografii jednoznacznej oceny. Powstałe w wyniku ustaleń kongresu wiedeńskiego z 1815 r. państwo to cieszyło się na początku swego istnienia sporym poparciem mieszkających w nim Polaków. Posiadało własną armię, administrację, bardzo liberalny jak na owe czasy ustrój, a dzięki trafnym decyzjom ówczesnego ministra skarbu księcia Ksawerego Druckiego-Lubeckiego szybko też znalazło się w dobrej kondycji gospodarczej.

Kongresówka miała jednakże także ciemniejsze karty. Już w kilka lat po jej utworzeniu pojawiły się pierwsze przejawy łamania przez władze konstytucji i prześladowania grup temu się sprzeciwiających. W rezultacie doprowadziło to do wybuchu w 1830 r. powstania nazywanego dziś listopadowym. Z perspektywy tego antyrosyjskiego wystąpienia często postrzega się Królestwo Polskie nie jako równorzędny I Rzeczypospolitej przejaw polskiej państwowości, ale jako niesuwerenny twór poddany rosyjskim wpływom protektoratu.

Warto jednak przy tym zwrócić uwagę, że formą powiązania ówczesnego Królestwa Polskiego z Cesarstwem Rosyjskim była unia, czyli kolejna w dziejach próba złączenia się Polski z innym państwem. Najdłużej istniejącą w polskiej historii unią była unia z Litwa, która 
choć spotyka się z krytycznymi ocenami, nie jest postrzegana, w przeciwieństwie do tej z 1815 r., jako forma obcej zależności. Wysuwane zaś w XVI i XVII w. projekty unii Rzeczypospolitej i Rosji rozpatrywane są wręcz $w$ kategoriach straconej szansy na rozprzestrzenienie się polskich wpływów daleko na wschód. Pożądane wydaje się zatem porównanie podstaw prawnych tych związków państwowych, aby stwierdzić, czy często spotykana negatywna ocena pozycji międzynarodowej Królestwa Polskiego w latach 1815-1831, w odróżnieniu od tej odnoszącej się do czasów unii lubelskiej i projektów unii z Rosją, jest zasadna.

Niniejsze opracowanie ma na celu analizę statusu prawnego Królestwa Polskiego na tle unii polsko-litewskiej oraz projektów unii Rzeczypospolitej i Rosji. Porównanie tych rozwiązań prawnych pozwoli sformułować bardziej obiektywną ocenę tego okresu w polskich dziejach, opartą bowiem na analizie prawnej zasad związku łączącego Królestwo Polskie z Cesarstwem Rosyjskim. Tym samym możliwe będzie przedstawienie, jaką pozycję prawną miało Królestwo Polskie w stosunku do Rosji i jakimi instrumentami prawnymi do działania na arenie międzynarodowej wówczas dysponowało. Wskazane zostaną również podobieństwa i różnice między omawianymi związkami państw, a dzięki temu określony zostanie także status Polski z perspektywy zasad unii lubelskiej i projektowanych unii Rzeczypospolitej i Rosji ${ }^{1}$.

Okres unii polsko-rosyjskiej 1815-1831, jako ważny etap w polskich dziejach, był często opisywany m.in. w podręcznikach do historii państwa prawa czy prawa międzynarodowego. Z nowszych publikacji poruszających to zagadnienie należałoby tu wyróżnić System polityczny, prawo, konstytucja i ustrój Królestwa Polskiego pod red. L. Mażewskiego. Z kolei projekty federacyjne I Rzeczypospolitej doczekały się wnikliwej analizy w pracy J. Malca pt. Szkice z dziejów federalizmu i myśli federalistycznej w czasach nowożytnych. Dotychczas brak jednakże książek czy artykułów naukowych, które poddawałaby porównaniu unie oraz próby unii z czasów I RP z unią łączącą Królestwo Polskie i Rosję w latach 1815-1831.

${ }^{1}$ Należy podkreślić, że w niniejszym artykule celowo pominięte zostały kwestie praktyki stosowania prawa jako irrelewantne dla oceny konstrukcji prawnych, co jest głównym celem tego artykułu. 


\section{Królestwo Polskie - okoliczności powstania i ustrój}

Jak już wspomniano, Królestwo Polskie powstało w wyniku postanowień kongresu wiedeńskiego. Zgodnie z art. 1 ust. 1 Aktu Końcowego Kongresu z dnia 9 czerwca 1815 r. $^{2}$ Księstwo Warszawskie, za wyjątkiem Wielkopolski i okręgu krakowskiego, połączone miało zostać z Cesarstwem Rosyjskim. W artykule podkreślono, że obszar przyszłego Królestwa Polskiego będzie z Rosją "nieodwołalnie związany konstytucją i będzie należał do cesarza Wszech Rosji i jego spadkobierców i następców po wieczne czasy". W tym samym artykule car zastrzegał sobie prawo do nadania temu państwu, wedle własnej woli, „rozciągłości wewnętrznej”. Ponadto mógł on też, od tego momentu, przybrać tytuł króla Polski ${ }^{3}$.

Utworzone na tej podstawie Królestwo Polskie zajmowało powierzchnię 128,5 tys. $\mathrm{km}^{2}$ i było zamieszkane przez 3,3 miliona ludzi. Z pozostałych ziem Księstwa Warszawskiego utworzono Wielkie Księstwo Poznańskie w granicach Królestwa Prus oraz podległy kontroli trzech mocarstw zaborczych okręg autonomiczny na obszarze Krakowa i terytorium przyległego, nazwany Wolne Miasto Kraków ${ }^{4}$.

Powstanie Królestwa Polskiego było realizacją jednego z pomysłów pojawiających się po upadku Rzeczypospolitej Obojga Narodów, zakładających odrodzenie tego państwa w oparciu o związek z Rosją. Takie stanowisko wyrażali m.in. książę Michał Kleofas Ogiński ${ }^{5}$ oraz książę Adam Jerzy Czartoryski. Ten ostatni w 1804 r. opracował tzw. plan puławski. Zgodnie z nim ziemie polskie miały zostać zjednoczone pod berłem Romanowów w federacyjnym państwie. Książę przedstawił nawet osobiście ten pomysł carowi Aleksandrowi I podczas jego pobytu w Puławach,

${ }^{2}$ Artykuły o podobnym brzmieniu znalazły się również w traktacie rosyjsko-pruskim oraz rosyjsko-austriackim z 3 V 1815 r. Zob. Traktat Przyjaźni zawarty w Wiedniu 3 V 1815 r. między Cesarstwem Rosyi a Królestwem Prus, Dziennik Praw Królestwa Polskiego, 1816, t. 2, s. 348-413; Traktat Przyjaźni zawarty w Wiedniu 3 V 1815 r. między Cesarstwem Rosyi a Cesarstwem Austryi, Dziennik Praw Królestwa Polskiego, 1816, t. 2, s. 294-347.

${ }^{3}$ Akt Końcowy Kongresu Wiedeńskiego, w: Królestwo Polskie. Dokumenty historyczne dotyczace prawno-politycznego stosunku Królestwa Polskiego do Cesarstwa Rosyjskiego, Warszawa-Lublin-Łódź 1915.

${ }^{4}$ A. Chwalba et al., Polska na przestrzeni wieków, Warszawa 2007, s. 402.

${ }^{5}$ P. Łazor, Aleksander o sprawie polskiej w Pamiętniku... księcia Michała Kleofasa Ogińskiego. Przyczynek do genezy Królestwa Polskiego, w: System polityczny, prawo, konstytucja i ustrój Królestwa Polskiego 1815-1830, pod red. L. Mażewskiego, Radzymin 2013, s. 53-65. 
zachęcając przy tym do odebrania zajętych przez Prusy polskich prowincji. Ostatecznie plan ten nie spotkał się $\mathrm{z}$ aprobatą ${ }^{6}$, choć koncepcja takiego odtworzenia Rzeczypospolitej nie została do końca zarzucona.

Książę Adam Jerzy Czartoryski, jako doradca cara, brał udział w obradach kongresu wiedeńskiego, gdzie opracował Zasady Konstytucji Królestwa Polskiego. Już w czerwcu 1815 r. zaczęły one obowiązywać na terenie Królestwa i stały się podstawą przyszłej Konstytucji, nadanej 27 listopada 1815 r. przez Aleksandra I ${ }^{7}$.

Już w art. 1 tego aktu zaznaczono, że Królestwo Polskie i Cesarstwo Rosyjskie są połączone ze sobą na zawsze. Łączącym je podmiotem była osoba władcy, którym zostawał każdorazowo rosyjski cesarz. Wspólna z Cesarstwem była również polityka zagraniczna. Jednak to do króla należała decyzja, które umowy międzynarodowe będą dotyczyć Królestwa, a także w których wojnach Rosji państwo to będzie brało udział. W Konstytucji znalazło się również zastrzeżenie dotyczące tego, że wojsko polskie nie zostanie użyte poza granicami Europy.

W wypadku nieobecności króla w Królestwie władzę w jego imieniu miał sprawować namiestnik stojący na czele rządu, którym była Rada Administracyjna. Przewidziano też istnienie Sejmu złożonego z króla, izby poselskiej i senatu oraz osobnego skarbu, administracji i sądownictwa. Konstytucja gwarantowała ponadto nietykalność osobista, nietykalność własności, wolność prasy i wyznania8.

\section{Unia lubelska}

Polska ma długą tradycję tworzenia z innymi państwami wspólnych organizmów. Niewątpliwie przełomową w polskiej historii unia, będącą również podstawą rozważań i projektów unii z Rosją była unia lubelska z 1569 r. między Królestwem Polskim i Wielkim Księstwem Litewskim. Jej zawarcie było konsekwencją długiego procesu, trwającego od 1385 r., kiedy to Polskę i Litwę po raz pierwszy połączyła osoba wspólnego władcy9.

${ }^{6}$ J. Skowronek, Adam Jerzy Czartoryski 1770-1861, Warszawa 1994, s. 162-173; A. Szwarc, M. Urbański, P. Wieczorkiewicz, Kto rządził Polska, Warszawa 2007, s. 507-508.

${ }^{7}$ Historia dyplomacji polskiej (połowa X-XX w.), t. 3, pod red. L. Bazylowa, Warszawa 1982, s. 133.

${ }^{8}$ Konstytucja Królestwa Polskiego, Dziennik Praw Królestwa Polskiego, 1816, t. 1, s. $2-103$.

${ }^{9}$ J. Żerbiłło Łabuński, Unia-Litwy z Polską (1385-1569), Warszawa 1913, s. 2-12. 
Zawarcie unii w 1569 r. poprzedziły trwające od 10 stycznia do końca czerwca obrady sejmów koronnego i litewskiego w Lublinie ${ }^{10}$. Zgodnie z podpisanym 1 lipca aktem unii obydwa te państwa zostały połączone ze sobą osobą władcy, wybieranego na wspólnej elekcji. Wspólny miał być również Sejm złożony z króla, izby poselskiej i senatu. Osobne pozostały natomiast wojsko, skarb, administracja, urzędy, sądownictwo oraz prawo. Na mocy unii powstał nowy podmiot prawa międzynarodowego - Rzeczpospolita Obojga Narodów - który prowadził jedną politykę zagraniczną i obronną ${ }^{11}$.

W historiografii nie ma jednoznacznej zgody co do oceny charakteru ustrojowego tego państwa. Większość doktryny stoi na stanowisku, że unia lubelska była unią realną ${ }^{12}$, czyli związkiem państw połączonych wspólnym organem (najczęściej jest to osoba monarchy) i tworzących przez to jeden podmiot prawa międzynarodowego ${ }^{13}$. Zdaniem niektórych badaczy państwa tworzące taki związek mogą zachować pewną podmiotowość $\mathrm{w}$ relacjach międzynarodowych ${ }^{14}$. Często wskazuje się również, że powstała w ten sposób Rzeczpospolita Obojga Narodów była federacją ${ }^{15}$. Przeciwnego zdania jest W. Uruszczak określający unię lubelską mianem unii zjednoczeniowej, a Rzeczpospolitą Obojga Narodów państwem jednolitym (unitarnym) ${ }^{16}$.

\section{Próby unii Rzeczypospolitej i Rosji}

Unia z 1815 r. była w dziejach Polski pierwszym i jak dotąd jedynym zrealizowanym projektem połączenia węzłem unii Polski i Rosji. Pomysły takie pojawiały się jednak również wcześniej. Po raz pierwszy

${ }^{10}$ P. Żywiecki, Art. 1-3 konstytucji Królestwa Polskiego z 1815 r. Unia rosyjsko-polska z 1815 r. a unia Księstwa Warszawskiego z Saksonia z 1807 r. i unia lubelska z 1569 r., w: System polityczny, prawo, konstytucja i ustrój..., s. 327-328.

${ }_{11}$ Akt unii lubelskiej, Volumina Legum, t. 2, s. 87-98.

${ }^{12}$ J. Bardach, B. Leśnodorski, M. Pietrzak, Historia ustroju i prawa polskiego, Warszawa 2009, s. 185; Z. Kaczmarczyk, B. Leśnodorski, Historia państwa i prawa Polski, t. 2, Warszawa 1966, s. 39; S. Kutrzeba, Unia Polski z Litwa, Lwów 1914, s. 209.

${ }^{13}$ L. Oppenheim, R. Roxburgh, International Law: A Treatise, vol. 1, Clark, NJ 2005, s. 154.

${ }^{14}$ L. Ehrlich, Prawo narodów, Kraków 1947, s. 108. Przeciwnego zdania był J. Makowski. Zob. J. Makowski, Podręcznik prawa międzynarodowego, Warszawa 1948, s. 198.

15 J. Bardach, B. Leśnodorski, M. Pietrzak, op. cit., s. 185; P. Żywiecki, op. cit., s. 328.

${ }^{16}$ W. Uruszczak, Historia państwa i prawa polskiego, t. 1: 966-1795, Warszawa 2010, s. 206-208. 
miało to miejsce w 1573 r. Wówczas, w czasie wolnej elekcji, jako jednego z poważniejszych kandydatów do korony polskiej rozpatrywano Wielkiego Księcia Moskiewskiego, który sam siebie tytułował carem, Iwana IV, zwanego Groźnym. Osadzenie na tronie Rzeczypospolitej tego władcy sąsiedniego państwa łączono z pomysłem połączenia pod jednym berłem obu tych państw. Warto zaznaczyć, że propozycja ta cieszyła się w owym czasie dość sporą popularnością, w szczególności w kręgach szlachty litewskiej. W październiku 1572 r. Litwa przedstawiła stronie rosyjskiej nawet plan osadzenia najpierw jedynie na tronie Wielkiego Księstwa Litewskiego syna rosyjskiego cara, Fiodora. Miało to postawić Koronę przed faktem dokonanym i zmusić do wybrania na elekcji tego właśnie kandydata ${ }^{17}$.

W 1573 r. do Moskwy udał się poseł Michał Haraburda, który miał dowiedzieć się o możliwości obrania Iwana Groźnego władcą całej Rzeczypospolitej. Car postawił jednak własne warunki wstąpienia na tron polski. Iwan IV żądał, aby po koronacji na króla Polski i Wielkiego Księcia Litewskiego tytułowano go w kolejności: „Cesarz (imperator) Wszech Rosji, Moskiewski, Włodzimierski, Nowogrodzki, Kijowski, Król Polski, Wielki Książę Litewski". Ponadto korona polska miała być dziedziczna dla jego potomstwa, a obranie go królem nie miało pociągać za soba zmiany religii. Tym samym koronacji miał dokonać metropolita rosyjski.

Co więcej, do Rosji miały zostać przyłączone Inflanty po Dźwinę oraz Kijów. W wypadku jednak, gdyby szlachta zdecydowała się na wybór nie jego, ale jego syna Fiodora, to żadne ziemie nie mogły zostać przyłączone do Rzeczypospolitej. Z kolei jeżeli nie doszłoby do obrania królem Polski ani jego, ani jego syna, Iwan IV wskazywał na Ernesta Habsburga jako najlepszego kandydata do tej korony. W czasie rozmów padły również sugestie w stosunku do Litwinów nakłaniające do zjednoczenia z Rosją i wspólnego podboju Polski.

Tak postawione warunki $\mathrm{w}$ połączeniu $\mathrm{z}$ zaniechaniem przez Iwana IV wysłania poselstwa w celu zdobycia poparcia dla własnej kandydatury spowodowały, że rosyjski władca bardzo szybko stracił poparcie, jakim cieszył się na początku. W rezultacie w czasie elekcji odpadł już w pierwszym głosowaniu. Warto dodać, że Iwana Groźnego rozpatrywano jako kandydata do korony polskiej także po ucieczce Henryka Walezego, lecz znów bez sukcesu.

${ }^{17}$ H. Wisner, Król i car: Rzeczpospolita i Moskwa w XVI i XVII wieku, Warszawa 1995, s. $21-22$. 
Pomysły obrania wspólnego władcy wysuwano także w latach 1584 i 1586, kiedy według planów to polski król Stefan Batory miał zostać osadzony na tronie w Moskwie. Wszystkie te projekty były z miejsca odrzucane przez stronę rosyjską i nie doczekały się bliższej konkretyzacji ${ }^{18}$.

Inaczej było z ponowną kandydaturą syna Iwana IV, już jako ówczesnego władcy Rosji, Fiodora, która pojawiła się w 1587 r. Tym razem to szlachta Rzeczypospolitej wobec niego przedstawiła zestaw warunków poparcia, które zakładały:

1. zmianę wiary przyszłego króla na katolicką;

2. zachowanie wolności szlachty z możliwością ich poszerzenia;

3. zjednoczenie ziem Królestwa Polskiego, Wielkiego Księstwa Litewskiego i Wielkiego Księstwa Moskiewskiego bez gwarancji sukcesji korony polskiej dla potomstwa przyszłego króla;

4. wspólną politykę obronną zjednoczonych państw;

5. zwrócenie przez Wielkie Księstwo Moskiewskie wszystkich ziem, jakie zagarnęło dotychczas Rzeczypospolitej;

6. wypłatę miliona monet moskiewskich na wspólną walkę w obronie granic;

7. wzniesienie trzydziestu zamków wzdłuż granic wraz z załogą;

8. ponoszenie dziesiątej części kosztów utrzymania swego dworu;

9. opuszczenie części Inflant;

10. wykup królewszczyzn oddanych w zastaw;

11. otwarcie portów na wschodnim Bałtyku;

12. nawiązanie kontaktów handlowych między Wilnem a Moskwą;

13. zrzeczenie się tytułu Wielkiego Księcia Moskiewskiego na rzecz tytułu Króla Polski;

14. wystawienie pięćdziesięciotysięcznej armii dla obrony Królestwa Polskiego;

15. podźwignięcie praw ${ }^{19}$.

Na takie warunki car Fiodor się nie zgodził, jednak nie zrezygnował ze starań o polską koronę. W przeciwieństwie do swego ojca wysłał na elekcję specjalne poselstwo, które miało przekonywać szlachtę do obrania go królem. Wówczas rosyjskie bojarstwo przedstawiło nowy projekt unii Rzeczypospolitej i Rosji, który zakładał samodzielność obydwu podmiotów rządzonych według własnych praw, lecz pod

${ }_{18} \mathrm{~J}$. Malec, Szkice z dziejów federalizmu i myśli federalistycznej w czasach nowożytnych, Kraków 1999, s. 13-18.

19 Ibidem, s. 21. 
berłem jednego władcy. Obywatele tego państwa mieliby możliwość swobodnego przesiedlania się. Ustąpiono w kwestii dziedziczności tronu i po śmierci Fiodora miała nastąpić nowa elekcja. Nie zmieniono jednak stanowiska w sprawie wyznania nowego władcy, co dla polskiej szlachty miało duże znaczenie i mocno zaważyło na odrzuceniu carskiej kandydatury ${ }^{20}$.

Do kolejnej próby zawarcia unii, na dodatek jednej z najpoważniejszych, doszło w październiku 1600 r., kiedy to kanclerz wielki litewski Lew Sapieha przedstawił w Moskwie carowi Borysowi Godunowowi dosyć szczegółowe warunki połączenia Rzeczypospolitej i Wielkiego Księstwa Moskiewskiego. Celem tego projektu miało być zapewnienie wiecznego pokoju (lub przynajmniej długotrwałego rozejmu) oraz pomocy wzajemnej w walce $z$ Turcją i Tatarami. Zdobyte ziemie we wspólnych wojnach miały być dzielone bądź pozostawać we wspólnym zarządzie. Taki zarząd proponowano zaprowadzić od razu nad Narwą i Iwanogrodem.

We wspólnym państwie zapewniona miała być swoboda przemieszczania się, kupowania ziemi, osiedlania się i zawierania małżeństw między przedstawicielami różnych nacji i wyznań. Zakładano również wzajemną wymianę zbiegów i złoczyńców, możliwość budowy cerkwi prawosławnych w Rzeczypospolitej i kościołów katolickich w Rosji. Młodzież rosyjska uzyskałaby możliwość nauki w szkołach Rzeczypospolitej, a szlachta do służby na dworach obydwu władców. Pomiędzy Rzeczpospolitą a Rosją planowano ustanowić wolność handlu. Zapowiadano również powołanie instytucji wspólnych, stałych posłów do państw trzecich, a ważniejsze poselstwa miano odbywać wspólnie. Wspólna miała być także moneta i skarb usytuowany w Kijowie. Postulowano też powołanie wspólnej floty na Morzu Czarnym i Morzu Bałtyckim.

Elekcje w Rzeczypospolitej odbywałyby się przy udziale posłów cara, a nowo wybrany władca miał mieć obowiązek zaprzysiąc związek obu państw. W wypadku bezpotomnej śmierci króla Polski tron przypadałby Wielkiemu Księciu Moskiewskiego, który przebywałby dwa lata w Polsce, rok na Litwie i rok w Moskwie. Pod jego nieobecność w Rosji rządy $\mathrm{w}$ jego imieniu sprawowałby jego syn wraz trzema osobami w radzie. $Z$ kolei bezpotomna śmierć cara miała skutkować przejęciem tronu przez króla Polski. Wielki Książę Moskiewski uzyskałby również zgodę na posługiwanie się tytułem cara i brata królewskiego.

${ }^{20}$ P. Kasztelan, Polsko-moskiewskie stosunki dyplomatyczne przełomu XVI/XVII wieku, Poznań 2014, s. 155. 
W projekcie nie przewidywano zmiany granic między obydwoma państwami. W wypadku pojawienia się konfliktów na tym tle zakładano powołanie specjalnej komisji mieszanej złożonej z przedstawicieli obydwu stron. Symbolem zjednoczonego państwa chciano uczynić dwie korony, a samo zjednoczenie miały zaprzysiąc obie strony ${ }^{21}$.

W odpowiedzi car wyraził zgodę na pokój wieczysty, jednakże wyraził dezaprobatę wobec faktu tytułowania króla Polski panem Inflant. Sprzeciwił się również mieszanym małżeństwom, kupowaniu ziemi przez obywateli jednego państwa na terytorium drugiego, choć nie wyrażał zastrzeżeń co do kwestii swobodnego przesiedlania się ludności na terytorium wspólnego państwa. Nie wyrażono też zgody na budowanie świątyń katolickich na terytorium Rosji, wspólną mennicę i symbol dwóch koron. Borys Godunow zgodził się natomiast na swoje kandydowanie w polskiej elekcji oraz wzajemne wydawanie złoczyńców i zbiegów. Sprawę obrony przed Tatarami sugerowano odłożyć do czasu podpisania wspomnianego pokoju. Natomiast w kwestii floty poproszono o konkretyzację tej propozycji ${ }^{22}$.

Sceptycyzm strony rosyjskiej wobec wielu polsko-litewskich postulatów znacząco osłabił szansę na realizację tego projektu. Polscy posłowie, chcąc go ratować, wysuwali jeszcze możliwość, po wyborze Wielkiego Księcia Moskiewskiego na króla Polski, dokonywania elekcji w obrębie jego dynastii. Strona rosyjska jednakże podnosiła dodatkowo kwestie Inflant i natychmiastowego uznania tytułu cara. Ostatecznie 4 marca 1601 r. podpisano tylko rozejm na dwadzieścia lat, w którym z warunków projektowanej unii znalazł się jedynie punkt o wydawaniu zbiegów i złoczyńców ${ }^{23}$.

Kolejne propozycje unii polsko-rosyjskiej wiążą się z okresem Dimitriad. Jeden z projektów wysuwał Dymitr Samozwaniec I, który dążył do połączenia pod swym berłem Rzeczypospolitej i Rosji ${ }^{24}$. Bardziej skonkretyzowany plan pojawił się po wkroczeniu wojsk Stanisława Żółkiewskiego do Moskwy w 1610 r. Delegacja bojarów przedstawiła wówczas hetmanowi warunki, od których uzależniano wybór królewicza Władysława Wazy na carski tron.

${ }^{21}$ J. Malec, op. cit., s. 24-25.

${ }^{22}$ Ibidem, s. 25-26.

${ }^{23}$ Historia dyplomacji polskiej (połowa $X-X X$ w.), t. 2, pod red. Z. Wójcika, Warszawa 1982, s. 59; J. Malec, op. cit., s. 26; K. Tyszkowski, Poselstwo Lwa Sapiehy do Moskwy, Lwów 1927, s. 39-59; H. Wisner, op. cit., s. 34-35.

${ }^{24}$ W. Sobieski, Zabiegi Dymitra Samozwańca o koronę polska, Kraków 1908, s. 2. 
Zdaniem bojarów koronacja nowego władcy miała się odbyć w obrządku prawosławnym. Sam Władysław miał również przejść na tę wiarę. Podkreślono przy tym, że w Rosji ma obowiązywać tylko to wyznanie, a nawracanie siłą na wiarę katolicką i jakąkolwiek inną oraz budowa kościołów katolickich będzie zakazana.

Postulowano, żeby dotychczasowi urzędnicy pozostali na swoich stanowiskach. Nienaruszone zostałyby również ich uposażenia oraz dobra szlachty. Wszelkie zmiany w tym zakresie car mógł dokonywać jedynie wespół z radą bojarską. Zabraniano przy tym rozdzielania stanowisk między obywateli Rzeczypospolitej, a Polacy i Litwini, którzy pozostaliby na dworze nowego cara, byliby opłacani z jego kieszeni. Zakazano skazywania i konfiskaty majątków bojarów bez wyroku sądowego. Zastrzeżono jednak, że sądy będą mogły działać wyłącznie na prawie rosyjskim. Zapowiedziano również uwolnienie jeńców oraz zaniechanie szukania pomsty przez obie strony trwającej wojny. Podatki i handel miały pozostać niezmienione. Zastrzeżono dalsze istnienie poddaństwa oraz zakaz przemieszczania się chłopów w obrębie kraju.

Ponadto zapowiedziano zawarcie pokoju wieczystego między Rzeczpospolitą i Rosją oraz wspólne prowadzenie polityki wojennej. Zdobyte dotychczas w czasie trwania tego konfliktu miasta miały zostać Rosji zwrócone za wykupem, a wojska polskie cofnięte do granicy. Nakazywano złapanie i stracenie Dymitra Samozwańca II, a Polacy z jego świty, w tym wojewoda Mniszech i jego córka Maryna, mieli zostać odesłani do Polski. Marynę pozbawiono też prawa do używania tytułu carycy rosyjskiej. Wojska polsko-litewskie (powyżej dwudziestu ludzi) otrzymały zakaz wstępu do Moskwy. Postulaty zakończono prośbą do Zygmunta III Wazy o zgodę na przejście syna na prawosławie i zatwierdzenia przedstawionych warunków ${ }^{25}$.

Pomimo zgody hetmana Żółkiewskiego i samego królewicza Władysława na powyższe postulaty plan ten pogrzebała nieprzejednana postawa króla Zygmunta III, który liczył na to, że sam zasiądzie na tronie moskiewskim. W 1611 r. wybuchło w Rosji antypolskie powstanie. Po roku doprowadziło ono do usunięcia polsko-litewskich wojsk z Moskwy. W 1613 r. Sobór Ziemski obrał nowym carem Michała Romanowa. Późniejsze wyprawy wojsk Rzeczypospolitej nie doprowadziły do odzyskania rosyjskiej stolicy ${ }^{26}$.

\footnotetext{
${ }^{25}$ J. Malec, op. cit., s. 31.

${ }^{26}$ Historia dyplomacji polskiej (połowa X-XX w.), t. 2, s. 63-67.
} 
Projekty połączenia ze sobą Rzeczypospolitej i Rosji ostatni raz pojawiły się w latach 1656-1658. Polska strona uzależniała osadzenie na swoim tronie rosyjskiego cara Aleksego Romanowa od jego przejścia na katolicyzm i zamieszkania w Rzeczypospolitej. Były to warunki nie do zaakceptowania dla strony rosyjskiej. Tym samym plany te, podobnie jak poprzednie, zakończyły się fiaskiem ${ }^{27}$.

\section{Unia polsko-rosyjska a unia lubelska oraz projekty unii Rzeczypospolitej i Rosji}

Porównując unię polsko-rosyjską z 1815 r. do unii lubelskiej i prób jej rozszerzenia o Rosję, należy na początku zwrócić uwagę na okoliczności, w jakich doszło do jej utworzenia. Unia Królestwa Polskiego i Cesarstwa Rosyjskiego była stronie polskiej narzucona. Car Aleksander I uzyskał na kongresie wiedeńskim prawa do części terytorium Księstwa Warszawskiego i zaprowadzenia tam wedle swojej woli ustroju. Dążenie Rosji do takiego rezultatu negocjacji w Wiedniu, zdaniem S. Huberta, może sugerować jedynie chęć utrzymania zajętych ziem, a nie restytucji państwa polskiego ${ }^{28}$. Polska oficjalnie nie była strona ani negocjacji wiedeńskich, ani ustalania zasad unii z Cesarstwem Rosyjskim ${ }^{29}$. Kontrastuje to mocno z wielomiesięcznymi negocjacjami przedstawicieli Korony i Litwy, które poprzedziły zawarcie unii lubelskiej w 1569 r., oraz przytoczonymi powyżej okolicznościami związanymi z próbami zawarcia związku państwowego między Rzeczpospolitą i Rosją.

Chcąc wskazać pierwszy punkt styczny omawianych unii oraz projektów, na pewno należałoby się skupić na aspekcie wspólnego władcy. W większości powyższych propozycji unii Rzeczypospolitej i Rosji to władca rosyjski miał być osadzony na tronie polskim i to on miał być podstawą związku dwóch państw. W przypadku projektów z lat 1600 i 1610, choć obranie wspólnego władcy nie było podstawą zawieranej

\footnotetext{
${ }^{27}$ J. Malec, op. cit., s. 33-34.

${ }^{28}$ S. Hubert, Rozbiory i odrodzenie Rzeczypospolitej: zagadnienie prawa międzynarodowego, Lwów 1937, s. 122.

${ }^{29} \mathrm{~W}$ takich kategoriach nie należy rozpatrywać udziału księcia Adama Jerzego Czartoryskiego, który co prawda w obydwu tych wydarzeniach uczestniczył, pełniąc często niepoślednią rolę, niemniej formalnie, jako carski doradca, był przedstawicielem strony rosyjskiej.
} 
unii, to niewątpliwie przewidywano, że tak się stanie w przyszłości. Stąd np. dość szczegółowe odniesienia do kwestii sukcesji tronu w propozycji Lwa Sapiehy.

Sprawą dyskusyjną dla Rzeczypospolitej była często kwestia dziedziczności korony polskiej. Polska szlachta przywiązana do wyrażonej w akcie unii lubelskiej zasadzie wolnej elekcji oponowała przeciwko tego typu pomysłom, wykazując jednakże pewną elastyczność w kwestii elekcji w ramach jednej dynastii. Ze względu na fakt narzucenia w 1815 r. unii polsko-rosyjskiej kwestia sukcesji tronu nie stanowiła problemu. Królem Polski miał zostawać każdorazowo rosyjski car.

Niemniej zważywszy na wcześniejsze projekty unii z Rosja, kwestia osadzenia na tronie polskim rosyjskiego władcy nie powinna być tym czynnikiem, który można postrzegać jako coś, co może w jakikolwiek sposób deprymować pozycję międzynarodową Polski.

Kolejnym ważnym aspektem, który przewijał się w przedkładanych propozycjach unii, były sprawy wyznaniowe. W projekcie z $1600 \mathrm{r}$. pojawia się postulat budowy kościołów katolickich w Rosji i cerkwi w Rzeczypospolitej. Strona rosyjska mocno oponowała przeciwko takim pomysłom, czego wyraz dano w negocjacjach w 1610 r. Z kolei Iwan IV wyraźnie wskazywał na wyższość wiary prawosławnej nad katolicka, domagając się koronacji na króla Polski w tym właśnie obrządku z rąk metropolity rosyjskiego. $Z$ drugiej strony przy próbach wyboru cara Fiodora oraz cara Aleksego na króla pojawił się postulat ze strony polskiej, aby nowy władca zmienił wyznanie na katolickie.

Przyrównując to do sytuacji w Królestwie Polskim, konstytucja gwarantowała wolność religijna, lecz jedynie religię rzymskokatolicką obdarzono "szczególną opieką Rządu”, jako tę wyznawaną przez większość mieszkańców. Ponadto biskupi rzymskokatoliccy w liczbie odpowiadającej liczbie województw i jeden biskup greckokatolicki uzyskali możliwość zasiadania w senacie. Zachowano tym samym dominująca pozycję katolicyzmu w Polsce, choć nie mogło być mowy o jakiejkolwiek ekspansji tego wyznania w głąb Rosji. Warto jednak zwrócić uwagę, że jedyna koronacja na króla Polski, jaka w tym czasie miała miejsce, nie odbyła się w obrządku wschodnim. 24 maja 1829 r. na Zamku Królewskim w Warszawie Mikołaj I sam dokonał aktu koronacji korona, która podał mu prymas Jan Paweł Woronicz ${ }^{30}$. W ten sposób rosyjski car

${ }^{30}$ M. Getka-Kenig, Anonimowa scena Koronacji cesarzowej Aleksandry na królową Polski (1829-1830). Malarska wizja narodowego odrodzenia, czyli o dwóch wymiarach iluzji, „Rocznik Muzeum Narodowego w Warszawie" 2013, vol. 2, s. 378. 
ustąpił z jednego z warunków, jakie wysunął Iwan IV, aby koronacji na króla Polski dokonał metropolita rosyjski.

Inną zbieżnością jest poszanowanie odrębności prawnej państw unijnych. W Królestwie Polskim obowiązywał zupełnie inny porządek prawny niż w Cesarstwie Rosyjskim i prawo rosyjskie nie miało tu zastosowania. Podobny stan obowiązywał w Rzeczypospolitej Obojga Narodów, a o zachowanie tej zasady zabiegała nawet strona rosyjska podczas wysuwania projektów unii (np. w 1587 r.).

W Królestwie Polskim inaczej z kolei rozwiązano problem niemalże stałej nieobecności władcy w kraju. W propozycji kanclerza Sapiehy pojawia się pomysł czasowego podziału obecności władcy na trzy państwa. W 1815 r. rozwiązaniem tej kwestii miało być utworzenie urzędu namiestnika - osoby zastępującej króla pod jego nieobecność. Ta ustrojowa forma swoistego „wicekróla” do tej pory była całkowicie nieznana w polskiej tradycji ustrojowej.

Należy zwrócić jednak uwagę, że Królestwo Polskie w niektórych miejscach nawiązywało do tradycji I Rzeczypospolitej. Państwo było bowiem podzielone na województwa, a organem władzy ustawodawczej był Sejm złożony z króla, izby poselskiej i senatu.

Pozornie elementem wspólnym omawianych projektów unii i związków państwowych była też jednolitość polityki zagranicznej. Lew Sapieha proponował stronie rosyjskiej odbywanie wspólnych poselstw i utworzenie urzędów stałych posłów, którzy reprezentowaliby zjednoczone państwo $\mathrm{w}$ państwach trzecich. Co ciekawe, propozycja ta odbiegała od praktyki Rzeczypospolitej Obojga Narodów. W państwie tym wspólna polityka zagraniczna polegała bardziej na skoordynowaniu polityki dwóch oddzielnych państw niż na jej prowadzeniu przez jeden ośrodek.

Funkcjonowanie w Koronie i w Wielkim Księstwie Litewskim oddzielnych urzędów doprowadziło do zachowania pewnych ich kompetencji na polu międzynarodowym. Sprowadzało się to przede wszystkim do odpowiadania za politykę na konkretnych kierunkach. Kancelaria wielka litewska była odpowiedzialna za prowadzenie polityki zagranicznej na kierunku wschodnim, a kancelaria wielka koronna na zachodnim i południowym. Wszelkie próby naruszenia tego podziału były piętnowane ${ }^{31}$.

${ }^{31}$ H. Wisner, Wielkie Księstwo Litewskie, Korona Polska, Rzeczpospolita, "Przegląd Historyczny" 1976, t. 67, nr 4, s. 583-584. 
Ponadto pomimo prowadzenia jednej (skoordynowanej) polityki zagranicznej obydwa państwa zachowały zdolność do występowania w swoim własnym imieniu na arenie międzynarodowej. Poza wcześniej wspomnianym przypadkiem przedstawienia propozycji litewskiego tronu dla carewicza Fiodora Wielkie Księstwo w latach 1626 i 1627 zawarło także rozejmy ze Szwecja, które nie dotyczyły Korony ${ }^{32}$.

Ta odrębność we wspólności w działaniach na arenie międzynarodowej rzutowała również na inną wspólną dziedzinę, czyli politykę obronną. Korona i Wielkie Księstwo Litewskie posiadały odrębne armie. Istniało zatem silne przekonanie o tym, że każdy odpowiada za obronę swojego terytorium, choć dbano, aby dane działanie nie odbijało się negatywnie na sytuacji drugiego unijnego państwa. Najczęściej jednak działań zbrojnych w trakcie konfliktów Rzeczypospolitej nie prowadzono razem ${ }^{33}$.

Podobnie jak Korona i Wielkie Księstwo Litewskie, także Królestwo Polskie i Rosja posiadały odrębne armie. Tutaj również Królestwo zachowało pełną niezależność od Cesarstwa. W żadnym wypadku nie można powiedzieć, że wojsko Kongresówki podlegało dowództwu rosyjskiemu. Polscy żołnierze mieli konstytucyjną gwarancję niepodejmowania walki poza granicami Europy. Ani razu także wojsko polskie nie brało udziału w operacjach wojsk rosyjskich prowadzonych w tym okresie $^{34}$.

Jeśli chodzi o wspólność polityki zagranicznej Królestwa Polskiego i Cesarstwa Rosyjskiego, sprawa wyglądała już jednak inaczej. Przede wszystkim unia polsko-rosyjska nie stworzyła osobnego podmiotu prawa międzynarodowego. Utrzymana została odrębność obydwu podmiotów, jak to miało miejsce w wypadku Korony i Wielkiego Księstwa Litewskiego, ale nie została stworzona państwowość je łącząca.

Na tym tle pojawiają się kontrowersje co do oceny prawnej unii polsko-rosyjskiej ${ }^{35}$. Zdaniem B. Winiarskiego była to unia realna ${ }^{36}$. Z kolei Z. Stankiewicz twierdzi, że była to „unia dynastyczna z elementami unii

${ }^{32}$ J. Bardach, Związek Polski z Litwa, w: Polska w epoce Odrodzenia. Państwo społeczeństwo - kultura, pod red. A. Wyczańskiego, Warszawa 1986, s. 146.

${ }^{33}$ H. Wisner, Wielkie Księstwo..., s. 590.

${ }^{34}$ L. Mażewski, Kilka uwag o armii polskiej w latach 1814-1830 w kontekście porozumienia z rosyjskim domem panującym, regulacji konstytucyjnej i miejscu w systemie politycznym, w: System polityczny, prawo, konstytucja i ustrój..., s. 162-163.

${ }^{35}$ P. Żywiecki, op. cit., s. 327.

${ }^{36}$ B. Winiarski, Ustrój polityczny ziem polskich w XIX w., Poznań 1923, s. 101. 
realnej"37. S. Kutrzeba nazwał ją unią osobistą ${ }^{38}$, czyli związkiem państw połączonych osobą władcy, lecz nietworzących jednego podmiotu prawa międzynarodowego ${ }^{39}$.

Artykuł 8 Konstytucji Królestwa Polskiego stanowił: „stosunki polityki zewnętrznej Naszego Cesarstwa będą wspólne Naszemu Królestwu Polskiemu". Tym samym kwestia prowadzenia polityki zagranicznej Królestwa została scedowana na Rosję. Wyjątek zawierał art. 9, który przewidywał uczestnictwo Królestwa Polskiego w tych traktatach pokoju i handlowych, które wskazał panujący. Co więcej, w art. 41 zaznaczano, że król może nominować agentów dyplomatycznych i handlowych. Możliwość występowania przez Królestwo Polskie na arenie międzynarodowej zależała zatem od woli jego władcy. Zasadą jednak było oddanie tej sfery Rosji.

Niemniej w czasie krótkich dziejów Królestwa można zauważyć pewną aktywność w dziedzinie polityki zagranicznej. Działania w sferze międzynarodowej mógł poniekąd wykonywać minister sekretarz stanu, który przebywał stale przy boku cara, i to jemu miały być powierzone, zgodnie z art. 81 Konstytucji, stosunki zewnętrzne Królestwa. Tuż po kongresie wiedeńskim Aleksander I przymierzał się nawet do stworzenia czegoś w rodzaju ministerstwa spraw zagranicznych, noszącego nazwę „sekcji zagranicznej”. Na stanowisko kierownika tego urzędu przewidywano hrabiego Leona Potockiego. Choć pomysł pozostał niezrealizowany, to hrabia Potocki występował na forum międzynarodowym jako doradca cara do spraw Królestwa. Tak było np. w 1818 r. w czasie konferencji w Akwizgranie ${ }^{40}$.

Kolejną próbą utworzenia MSZ Królestwa Polskiego było powołanie w 1822 r. w Warszawie oddziału ministerstwa spraw zagranicznych Rosji usytuowanego przy Naczelnym Wodzu wielkim księciu Konstantym. Na czele tego urzędu stanął baron Paweł Mohrenheim, będący wówczas sekretarzem wielkiego księcia. Naczelny Wódz i jego oddział rosyjskiego MSZ uzyskał tym samym wgląd do dokumentów dyplomatycznych Cesarstwa i do prowadzenia oficjalnych rozmów z przedstawicielami dyplomatycznymi i konsularnymi innych państw ${ }^{41}$.

37 Z. Stankiewicz, Królestwo Polskie 1815-1863, w: Historia państwa i prawa Polski, t. 3, pod red. J. Bardacha, Warszawa 1981, s. 297.

${ }^{38}$ S. Kutrzeba, Historia ustroju, t. 3, Lwów 1920, s. 107.

${ }^{39}$ L. Oppenheim, R. Roxburgh, op. cit., s. 154.

${ }^{40}$ Historia dyplomacji polskiej (połowa X-XX w.), t. 3, s. 134 i 138.

${ }^{41}$ L. Mażewski, Królestwo Polskie z punktu widzenia prawa wewnętrznego i prawa narodów, w: System polityczny, prawo, konstytucja i ustrój..., s. 89. 
W okresie swego istnienia Królestwo było też kilkakrotnie stroną umów międzynarodowych. Chodzi tutaj o:

- Konwencję między Królestwem Polskim a Austrią względem długów Księstwa Warszawskiego zawartą 29 czerwca $1821 \mathrm{r}^{42}$,

- Akt ostateczny rozgraniczenia między Królestwem Polskim a Prowincjami Pruskimi z 24 kwietnia 1823 r. ${ }^{43}$,

- Konwencję stanowiąca wzajemne uchylenie opłaty detrakcyjnej między Królestwem Polskim a Prusami z 3 maja 1824 r. ${ }^{44}$,

- Konwencję między Cesarstwem Rosyjskim, Królestwem Polskim a Prusami urządzającą stosunki wzajemnego handlu i żeglugi z 11 marca 1825 r. $^{45}$,

- Akt ostateczny rozgraniczenia między Królestwem Polskim a Królestwem Galicyjskim z 26 grudnia 1826 r. ${ }^{46}$,

- Konwencję mającą na celu uregulowanie stosunków służby pocztowej między Królestwem Polskim a Prusami z 20 marca 1827 r. $^{47}$,

- Konwencję ostatecznej likwidacji z Dworem Austriackim z 29 kwietnia 1828 r. ${ }^{48}$,

- Konwencję likwidacyjną z Dworem królewsko-saskim z 16 września $1828 \mathrm{r}^{49}$

Z tej krótkiej praktyki można wywnioskować, że działania te nie mogły być sprzeczne z polityką prowadzoną przez Rosję, choć - jak widać - Królestwo mogło występować na arenie międzynarodowej jako

\footnotetext{
${ }^{42}$ Konwencja między Królestwem Polskim a Austrią względem długów Księstwa Warszawskiego zawarta 29 VI 1821 r., Dziennik Praw Królestwa Polskiego, 1825, t. 9, s. 3-39.

${ }^{43}$ Akt ostateczny rozgraniczenia między Królestwem Polskim a Prowincjami Pruskimi z 24 IV 1823 r., Dziennik Praw Królestwa Polskiego, 1824, t. 8, s. 109-147.

${ }^{44}$ Konwencja stanowiąca wzajemne uchylenie opłaty detrakcyjnej między Królestwem Polskim a Prusami z 3 V 1824 r., Dziennik Praw Królestwa Polskiego, 1825, t. 9, s. $75-89$.

${ }^{45}$ Konwencja między Cesarstwem Rosyjskim, Królestwem Polskim a Prusami urządzająca stosunki wzajemnego handlu i żeglugi z 11 III 1825 r., Dziennik Praw Królestwa Polskiego, 1825, t. 9, s. 112-153.

${ }^{46}$ Akt ostateczny rozgraniczenia między Królestwem Polskim a Królestwem Galicyjskim z 26 XII 1826 r., Dziennik Praw Królestwa Polskiego, 1827, t. 12, s. 58-111.

${ }^{47}$ Konwencja mająca na celu uregulowanie stosunków służby pocztowej między Królestwem Polskim a Prusami z 20 III 1827 r., Dziennik Praw Królestwa Polskiego, 1826, t. 11, s. 541-649.

${ }^{48}$ Konwencja o ostatecznej likwidacji z Dworem Austriackim z 29 IV 1828 r., Dziennik Praw Królestwa Polskiego, 1827, t. 12, s. 198-289.

${ }^{49}$ Konwencja likwidacyjna z Dworem królewsko-saskim z 16 IX 1828 r., Dziennik Praw Królestwa Polskiego, 1827, t. 12, s. 324-349.
} 
osobny od Cesarstwa podmiot. Należy zatem stwierdzić, że działania międzynarodowe Królestwa Polskiego z jednej strony czyniły zadość zasadzie wspólności polityki zewnętrznej, z drugiej - nadal podkreślały podległość tej sfery interesom Cesarstwa.

Można przypuszczać, że z czasem z oddziału ministerstwa spraw zagranicznych Rosji wyewoluowałby analogiczny urząd polski, co mogłoby też doprowadzić do stworzenia własnych przedstawicielstw dyplomatycznych i konsularnych ${ }^{50}$. Nie zmienia to jednak konstytucyjnej podstawy poddania się kierunkowi polityki zagranicznej Rosji. To każe uznać unię polsko-rosyjską za związek nierównoprawny, na korzyść strony rosyjskiej.

Ten aspekt najsilniej kontrastuje z zasadami unii lubelskiej oraz projektami unii Rzeczypospolitej i Rosji, gdzie starano się zachować równość podmiotów je tworzących. Dzieje Rzeczypospolitej Obojga Narodów, co prawda, pokazały, że to Korona, przede wszystkim przez ekspansję swojej kultury, stała się podmiotem dominującym w tym państwie $^{51}$. Niemniej jej ustrojowa pozycja była równa z Wielkim Księstwem Litewskim.

\section{Podsumowanie}

Odnosząc się do wskazanych na początku opracowania celów rozważań, należy stwierdzić, że jedynym zasadniczym aspektem, który powoduje różnicę w ocenie pozycji Polski w warunkach unii z 1815 r. z jej pozycją w unii lubelskiej i w projektach unii Rzeczypospolitej z Rosja, jest kwestia zasad prowadzenia wspólnej polityki zagranicznej. Spowodowana przez to nierówność podmiotów tworzących unię polsko-rosyjską nakazuje patrzyć na Królestwo Polskie jako, co prawda, odrębne od Rosji państwo, z pewną dozą samodzielności także na arenie międzynarodowej (czego dowodzi możliwość występowania w stosunkach zewnętrznych niezależnie od Cesarstwa Rosyjskiego), lecz mimo wszystko zależne w sferze

${ }^{50}$ Abstrahując od praktyki łamania konstytucji Królestwa, należy podkreślić, że decydujące znaczenie w tym kontekście miałyby ambicje wielkiego księcia Konstantego. Taki pogląd wyraża m.in. L. Mażewski. Zob. L. Mażewski, Królestwo Polskie..., s. 89-90.

${ }^{51}$ Co ciekawe, na podobny obrót spraw liczyło społeczeństwo polskie w okresie porozbiorowym. Wynikało to m.in. z faktu, że po 1815 r. szlachta dawnej Rzeczypospolitej stanowiła blisko połowę całej szlachty Imperium Romanowów. Zob. M. Jankowski, Dzieje inteligencji polskiej do roku 1918, t. 1: Narodziny inteligencji 1750-1831, Warszawa 2008, s. 112 i n. 
polityki zagranicznej. Zasady, na jakich opierała się unia polsko-rosyjska z 1815 r., trudno bowiem nazwać równymi. Można domniemywać, że było to wynikiem tego, iż unia została Polsce narzucona i w odróżnieniu od unii lubelskiej oraz prób zawarcia podobnej unii z Rosją Polska nie była stroną negocjującą jej zasady.

Wspólnymi elementami między Królestwem Polskim a Cesarstwem Rosyjskim była osoba władcy i polityka zagraniczna. Władcą Królestwa był każdorazowo rosyjski car. W wymiarze realnym nie miało to jednak aż tak wielkiego znaczenia. Zachowana odrębność prawna i ustrojowa powodowała, że nie istniała w związku z tym żadna zależność Królestwa od Rosji. Było to także zbieżne z niektórymi propozycjami unii Rzeczypospolitej i Rosji - zachowania odrębności prawnej przy wspólnym władcy.

Inaczej było z drugą wspólną materią, czyli polityką zagraniczną. Jedność tej dziedziny była podstawą unii lubelskiej i niektórych propozycji unii z Rosją z XVI i XVII w. Jednakże unia z 1815 r. nie stworzyła osobnego podmiotu prawa międzynarodowego, w odróżnieniu od unii z 1569 r. Natomiast art. 8 Konstytucji Królestwa wyraźnie wskazywał na podporządkowanie tej sfery Cesarstwu Rosyjskiemu. Odbiegało to bardzo od praktyki Rzeczypospolitej Obojga Narodów, w której tworzące ją podmioty prowadziły oddzielna, ale skoordynowaną politykę zagraniczną. Ponadto zarówno w projektach unii Rzeczypospolitej z Rosja, jak i w unii lubelskiej starano się zachować równość tworzących je podmiotów.

Warto zaznaczyć, że można wskazać kilka podobieństw łączących unię z 1815 r. z unią lubelską oraz z projektami unii z Rosją z XVI i XVII w. Obydwa państwa łączył jeden władca, zachowano odrębność prawna, religijną oraz wojskową. Ustrój w niektórych miejscach Królestwa Polskiego nawiązywał też do czasów I RP. Nie może to jednak zmienić oceny nierównomierności tego związku.

\section{THE POLISH-RUSSIAN UNION OF 1815 AGAINST THE BACKGROUND OF THE LUBLIN UNION AND DRAFTS OF OTHER UNIONS BETWEEN THE REPUBLIC OF POLAND AND THE RUSSIAN EMPIRE OF THE $16^{\text {TH }}$ AND $17^{\text {TH }}$ CENTURIES}

S u m m a ry

The lifetime of the Kingdom of Poland - a state connected with the Russian Empire by a union - has not been unequivocally assessed in Polish historiography. On the one hand, the Kingdom had its own army, administration and a very liberal 
constitution, and had quickly achieved economic prosperity. On the other hand, within a few years of its creation, there occurred the first violations of the Constitution and the persecutions of those who opposed these infringements. A significant event was the revolt of the Cadets of 29 November 1830, which turned into a uprising, today referred to as the November Uprising.

This article is the analysis of the legal aspects of the Polish-Russian union created in 1815. It is then compared with the Union of Lublin and the drafts of planned unions between the Polish-Lithuanian Commonwealth and the Tsardom of Russia in the $16^{\text {th }}$ and $17^{\text {th }}$ centuries. The circumstances which led to the creation of the Kingdom of Poland and its union with the Russian Empire, as well as the earlier attempts to create one state of the Polish-Lithuanian Commonwealth and the Russian Empire, as well as the principles of a union of the Crown of the Kingdom of Poland and the Grand Duchy of Lithuania are presented. The principles upon which these unions were to be based are subsequently compared and analysed. A particular emphasis has been placed on the issues related to the international legal status of the Kingdom of Poland. In this context questions such as: the treaty-making power and jus legationis have also been asked. Another important issue discussed in the paper is also the role of the king in matters concerning foreign policy and a possible role of Russia in these matters.

The results of this analysis allow to formulate a more objective assessment of the period of the Kingdom of Poland, focusing on its legal status and position, and in particular on the relation with the Russian Empire.

Keywords: Polish-Russian Union, Union of Lublin, Polish-Muscovite Union, Kingdom of Poland 